\title{
Microenterprise Dynamics in Developing Countries: How Similar are They to Those in the Industrialized World? Evidence from Mexico
}

\author{
Pablo Fajnzylber, William Maloney, and Gabriel Montes Rojas
}

\begin{abstract}
A rich panel data set from Mexico is used to study the patterns of entry, exit, and growth of microenterprises and to compare these with the findings of the mainstream theoretical and empirical work on firm dynamics. The Mexican self-employment sector is much larger than its counterpart in the United States, which is reflected in higher unconditional rates of entry into the sector. The evidence for Mexico points to the significant presence of well-performing salaried workers among the likely entrants into self-employment, as opposed to the higher incidence of poorer wageworkers among the entrants into the U.S. self-employment sector. Despite these differences, however, the patterns of entry, survival, and growth with respect to age, education, and many other covariates are very similar in Mexico and the United States. These strong similarities suggest that mainstream models of worker decisions and firm behavior are useful guides for policymaking for the developing-country microenterprise sector. Furthermore, they suggest that, as a first approximation, the developing-country microenterprise should probably be viewed as they are in the advanced countries as offering potentially desirable job opportunities to low-productivity workers.
\end{abstract}

This article examines whether microenterprises in developing countries behave similarly to their industrial country counterparts or whether they represent a separate phylum altogether. In industrial countries, the last two decades have seen the emergence of a set of stylized facts about the personal and firm characteristics associated with entry into self-employment, the survival and growth of existing microenterprises, and theoretical frameworks to explain them. However, notwithstanding the increasing importance given to the

Pablo Fajnzylber is senior economist in the Private Sector Development unit for Latin America and the Caribbean at the World Bank; his email address is pfajnzylber@worldbank.org. William F. Maloney is lead economist in the Office of the Chief Economist for Latin America at the World Bank; his email address is wmaloney@worldbank.org. Gabriel Montes Rojas is a PhD student in economics at the University of Illinois, Urbana-Champaign; his email address is rmontes@uiuc.edu. This research was financed by the regional studies program, Office of the Chief Economist for Latin America and the Caribbean at the World Bank. The authors are grateful for helpful discussions with Guillermo Perry, Chris Woodruff, and members of the 2006 Latin American Flagship Team on Informality. The article has also been much improved, thanks to the comments of the journal editor and three anonymous referees.

THE WORLD BANK ECONOMIC REVIEW, VOL. 20, NO. 3, pp. 389-419

doi:10.1093/wber/lhl005

Advance Access publication September 6, 2006

(C) The Author 2006. Published by Oxford University Press on behalf of the International Bank for Reconstruction and Development / THE WORLD BANK. All rights reserved. For permissions, please e-mail: journals.permissions@oxfordjournals.org. 
promotion of microenterprises and small enterprises in development policy circles, there has been no systematic attempt to see how their dynamics in developing countries approximate those described in the mainstream literature. ${ }^{1}$

This represents a loss on two fronts. First, if behavioral differences are not so great, development policymakers have a wealth of analytical frameworks at their disposal for informing analytical work and policymaking on microenterprises. Second, a finding of kinship with industrial country counterparts would provide additional evidence on the debate on how to conceive of the role of the informal microenterprise in the developing world. In Organization for Economic Cooperation and Development (OECD) countries, opening a business and being one's own boss is often celebrated as a desirable alternative to salaried work, whereas in the developing world, the very large unregulated (informal) self-employed sectors are frequently seen as the disadvantaged segment of a dual labor market where workers queue for good jobs. The two views have different implications for entry and firm dynamics.

This article uses a unique data set for Mexico that permits linking detailed microenterprise survey data with rotating household panel data sets. These data offer a select number of firm and individual characteristics that allow comparison with findings in the OECD firm dynamics literature: firm characteristics such as size and time in business; individual traits of entrepreneurs such as age and education; and, more speculatively, detailed firm information such as that on capital stocks and access to credit. This permits the examination of patterns of entry and exit and determinants of performance and survival. Although comparisons with the canonical studies for industrial countries are necessarily imperfect, there is a surprising degree of similarity.

\section{Conceptual Considerations}

The mainstream theoretical and empirical literatures have proceeded in tandem and offer both stylized facts and conceptual foundations that can be used in the analysis of the Mexican data. The brief review that follows serves mostly to motivate the variables included in the analysis and to provide benchmarks

1. Only 6 of the 53 articles mentioned by Blanchflower (2004) in his self-employment literature review are on developing countries, and they focus mostly on the determinants of earnings. To our knowledge, the only previous evidence on the determinants of entry, exit, and growth of microenterprises in developing countries are the papers on Africa by Mead and Liedholm (1998), Liedholm and Mead (1999), Liedholm (2002), McPherson (1995, 1996), and Goedhuys and Sleuwaegen (2000). There have been other recent studies on firm dynamics in developing countries, but they have focused mostly on larger firms. Roberts and Tybout (1997), for instance, worked mainly with industrial surveys, which generally had limited coverage of microenterprises. Aw, Chung, and Roberts (2003) studied Korean and Taiwanese firms with more than 10 employees. Bartelsman, Haltiwanger, and Scarpetta (2004) looked at creative destruction in 24 industrial and developing countries. For most countries (including Mexico), their data cover all plants with at least one employee. However, at least in the case of Mexico, the survey is based on social security registers that, by definition, lead to the exclusion of most microenterprises found in the informal sector. 
against which to compare the estimated Mexican parameters. Somewhat more tentatively, it highlights some contrasting predictions with the less-formalized dual labor market literature that permits distinguishing between two broad conceptions of the role of the sector.

The dominant view of the role of self-employment in industrial countries stresses the risk-taking, entrepreneurial nature of the sector, with the celebrated Silicon Valley high-technology start-up at its apex. In the classic framework proposed by Lucas (1978), individuals are endowed with a given-and knownlevel of entrepreneurial or managerial ability, which determines the returns from self-employment. Individuals with a sufficiently high level of managerial ability become entrepreneurs, whereas the rest become wageworkers. Moreover, there is evidence that, other things equal, some individuals may derive a larger utility from entrepreneurship than from wage work, thus reducing the net opportunity cost of entering self-employment. Evidence on this has been provided by Blanchflower and Oswald (1998), who reported that the self-employed report higher levels of job and life satisfaction and that half of U.S., U.K., and German workers would prefer to be self-employed, and by Hamilton (2000), who finds that nonpecuniary benefits-such as being your own boss-explain the lower conditional earnings generally found in the sector.

This view stands in contrast to the bulk of the developing-country literature that sees self-employment in the informal sector as a holding pattern for those rationed out of better jobs in the salaried sector, particularly young people. ${ }^{2}$ Rather than the patterns of entry and exit and growth associated with entrepreneurship dynamics, self-employment in developing countries is often viewed as disguised unemployment. There is some parallel with the industrial country sociological literature that sees the numerous self-employed among certain ethnic minorities as recruited from among "misfits"-individuals who lack access to salaried employment, for instance, because of language barriers, a history of unemployment, or limited labor market experience (see Evans and Leighton 1989; Carrasco 1999 and the references they cite). However, an emerging view with roots in Hart's $(1972,1973)$ early work on Ghana and Kenya stresses the mounting evidence of entrepreneurial dynamism, voluntary entry, and relative job satisfaction (De Soto 1989; Maloney 1999, 2004; Bhattacharaya 2002).

2. The dualistic view has intellectual roots perhaps best distilled in Harris and Todaro's (1970) vision of a market segmented by wage setting in the formal sector that leaves the traditional sector rationed out of modern salaried employment. The view of informal urban workers as the inferior or excluded segment became influential in the International Labour Organization and its Latin America affiliate, the Latin America Regional Employment Program (PREALC). See, for instance, Tokman (1978). Generally, this view partitions urban employment into a modern or formal sector (characterized by high productivity growth and job benefits) and a traditional or informal sector. These models typically view the informal sector as essentially stagnant and unproductive, serving as a refuge for the urban unemployed and as a receiving station for newly arriving rural migrants. However, sociological research on Mexico stresses the higher status and desirability of the sector (Balán, Browning, and Jelin 1973; Maloney 1999). 
Clearly, as in industrial countries, the sector is very heterogeneous. Fields (1990) noted the presence of "upper" and "lower" tiers among the informal firms, and Cunningham and Maloney (2001), using the same data employed here, identified several distinct subsectors that differ greatly by, among other characteristics, productivity, demographics, and reason for entry. Fully cognizant, therefore, of the need for nuance in approaching the analysis, what this article seeks to establish is whether, as a first approximation, the sector more closely approximates the mainstream view or whether, in fact, it appears as a pathological outcome of regulatory distortions requiring entirely different analytical tools.

\section{Growth and Failure}

The literature commonly finds that self-employment is extraordinarily risky, and several mainstream articles on industry dynamics have attempted to provide conceptual support for the observed patterns of microenterprise mortality. Jovanovic (1982) added dynamics to Lucas's view by further assuming that managerial ability is uncertain and that individuals can only gradually learn about a firm's true cost structure by opening and operating a business. Entry into self-employment involves a fixed cost, which only those with high expected ability and profits may be willing to pay.

After entry, entrepreneurs incorporate the information from their actual profits, revise their ability estimates, and adjust the level of profit-maximizing output accordingly. Firms with consistently lower-than-expected profits tend to contract and eventually go out of business, whereas firms with unexpectedly high profits cause entrepreneurs to revise their ability estimates upward and expand. Over time, survivors obtain more precise ability estimates and approach their steady-state size. Their behavior becomes less volatile: they fail less frequently, but they also expand less rapidly. Empirical evidence favoring these basic predictions on the negative links between time in business and size, on one hand, and firm exit and growth, on the other, was obtained for the United States by Evans (1987a, 1987b) and Dunne, Roberts, and Samuelson (1988, 1989); for Germany by Wagner (1994); and for the United Kingdom by Geroski (1991).

Other dynamic models also generate these patterns, although with different analytical structures. Ericson and Pakes $(1989,1995)$ proposed a model of active exploration-as opposed to the passive learning assumption in Jovanovic's (1982) model — that incorporates firm-specific sources of uncertainty derived from stochastic outcomes of investments made by firms to improve their profitability. Favorable outcomes from the firms' own investments-including those that led to entry into the industry-tend to move them toward "better" states, whereas good outcomes of direct competitors move them to less profitable states. ${ }^{3}$ In this context, profits and, somewhat in contradiction to the Jovanovic

3. As in Jovanovic's (1982) model, entry, exit, and investment decisions are made to maximize the expected discounted value of future net cash flows conditional on the current information set. 
model, higher capital stocks should decrease the probability of failure and be positively related to firm growth, all else being equal.

\section{Entry}

Hopenhayn's (1992) model of industry dynamics also generates broadly similar implications to Jovanovic's (1982) model and is especially notable for its analysis of the effect of changes in the cost of entry, which could be interpreted as an outside opportunity cost for some resources (for example, managerial ability) used by the firm. Higher costs of entry lead to a lower turnover rate because more ex ante selection occurs. This could be particularly relevant in developingcountry contexts characterized by higher levels of informality and lower productivity in the salaried sector, which in Hopenhayn's model would lead to a lower entrepreneurial ability threshold for entering self-employment and thus to higher entry and exit rates.

Offsetting this effect, however, may be other constraints to entry that may be exacerbated in the developing world, and this provides another contrasting prediction that enables distinguishing between different visions of the sector. Johnson (1978) and Jovanovic (1979) postulated that young people are likely to be less risk-averse and hence should be overrepresented among those entering self-employment, a pattern that would be observationally equivalent to the standard queuing view of developing-country labor markets. Young people rationed out of formal labor would tend to enter informal self-employed work. However, the reverse pattern is found in the United States: entry increases with age. As an explanation, Evans and Jovanovic (1989) offered a variation of Lucas's (1978) model in which binding liquidity constraints may lead individuals to delay or forgo profitable business opportunities, reducing entry rates and increasing exit rates among those with low personal assets-disproportionately the young. Offering something of a contrasting prediction to that of Ericson and Pakes $(1989,1995)$, they argue that because credit-constrained individuals are more likely to start small businesses with a suboptimal amount of capital, returns to capital will be higher, and smaller firms (with lower capital stocks) will grow faster than firms that entered closer to their steady state.

Either model of credit constraints to voluntary entry is largely inconsistent with the dualistic view of self-employment as an easy entry-holding pattern in several ways. Both the view of the self-employed as misfits and the dualistic view of informal labor markets would predict lower entry rates into self-employment coming from salaried work than from unemployment or from out of the labor market. However, the opposite prediction could be derived from the Evans and Jovanovic's (1989) view if individuals acquire more capital and knowledge of business opportunities—and to some extent their own managerial ability-while working than while unemployed or out of the labor market. In particular, if formal schooling is relatively poor and most relative human capital is accumulated on the job, salaried employment may be a logical stepping-stone to self-employment. 
Furthermore, the impact of the level of remuneration in previous jobs also potentially offers some insights that may help distinguish mainstream and dualistic models. All things equal, workers earning higher wages in salaried work would be less likely to be misfits, or unsuited to formal work, and so less prone to move into self-employment. However, in the presence of credit constraints, workers earning higher wages in the salaried sector may also be able to accumulate capital faster and so be more likely to enter self-employment. Moreover, there may be a correlation between previous productivity in the salaried sector, and thus level of remuneration, and entrepreneurial ability or at least competence in the chosen field of entrepreneurship. To the degree that this would imply a higher probability of success in self-employment, people with conditionally higher earnings in the formal sector might be expected to enter self-employment, whereas people with less skills may choose not to take the risks.

In sum, the impact of personal characteristics of existing and would-be entrepreneurs can help distinguish between the two views of the sector. In the segmented labor market scenario, unemployed individuals, young workers, those out of the labor force, and those with less schooling and lower wages should all be more likely to be self-employed, as they would be worse positioned for finding formal salaried jobs. In contrast, the mainstream literature suggests that older, better-educated, and well-paid workers with experience in the salaried sector should have a higher probability of entering, staying in, and growing in the self-employment sector as they should be more likely to have accumulated the assets required to start a business and be better positioned to find, assess, and take advantage of good business opportunities.

Finally, two additional covariates appear in the mainstream literature but yield ambiguous predictions. First, workers with more schooling might be expected to find better matches as salaried workers in larger firms that could better use specialized skills. By contrast, Rees and Shah (1986) and Cressy (1996) argued that the costs of assessing business opportunities may be lower for more educated individuals and that human capital may be a complement to managerial ability. This is suggested by Bates (1999), who showed that in the United States, the probability of survival of small businesses is positively related to the level of education of their owners.

Second, Carrasco (1999) argued that men who are married could be less willing to take risks. By contrast, Mexican sociologist González de la Rocha (1994) suggests that the possibility of combining the self-employment earnings of the household head or spouse with the salaries of other family members could reduce overall household income risk.

\section{Data and Methodology}

The analysis employs two data sets provided by the Mexican Statistical Institute (INEGI). The first is the National Urban Employment Survey [Encuesta Nacional 
de Empleo Urbano (ENEU)], which follows workers across a five-quarter period in a rotating panel framework. This survey records age, gender, education, marital status, labor market status, earnings, and some general characteristics of the jobs held by economically active individuals, such as firm size. The first and fifth interviews of individuals covered in this survey between 1987 and 2001 are linked to construct a two-period panel data set that permits analysis of entry, survival, and growth in the self-employment sector. The labor market status of the surveyed individuals is established based on the characteristics of their main job during the week preceding the survey. Individuals who report that in their main job they were either "employers" (patrones) or "own-account workers" (trabajador por su cuenta) are defined as self-employed. ${ }^{4}$

The second data source is the National Survey of Microenterprises [Encuesta Nacional de Micronegocios (ENAMIN)], which in 1992, 1994, 1996, and 1998 reinterviewed a sample of the self-employed individuals covered in previous rounds of the ENEU. These surveys ask detailed questions on the characteristics of firms with up to five employees (15 in manufacturing), including information on capital stock, time in business, and access to credit from formal and informal sources, both for starting the business and at a later time. To study the effects of these characteristics on the survival and growth of microenterprises, we linked the ENAMIN sample with the panel data set constructed from the ENEU data.

To study the determinants of entry into self-employment, we first constructed a random sample of 30 percent of all men aged 15-65 years covered in the longitudinal data set constructed from the ENEU. ${ }^{5}$ Analysis is restricted to the behavior of self-employed men and male-headed microenterprises, which represent, respectively, 65 percent of Mexican self-employed and 70 percent of the microenterprises surveyed by ENAMIN. This sample encompasses individuals who are out of the labor force, unemployed, or working. The working group includes both salaried and contract workers, as well as individuals working without pay on cooperatives and in other unspecified jobs. The subsample of salaried individuals is also used to investigate the role of conditional wages and firm size.

In the same vein as Evans and Leighton (1989), these data are used to estimate a probit model of the determinants of entry into self-employment, looking in particular at the role of the age of potential entrepreneurs, their education levels,

4. In a nutshell, the self-employed category includes all individuals whose main job consists of working in their own businesses. This is similar to the standard definition used in the U.S. self-employment literature. Evans and Leighton (1989), for instance, define as self-employed all sole proprietors, partners, and sole owners of incorporated businesses. ENEU provides information on whether individuals have a second job but provides no income information for that job. Thus, it is not possible to calculate the fraction of total income derived from self-employment, which is why the self-employed are distinguished from other individuals based only on whether self-employment is the primary job and not on a particular cutoff for the ratio of self-employment to wage income, because that information is not available.

5. Preliminary explorations suggest some differences in the dynamics of female-headed microenterprises, but these are not examined in this article. 
previous labor market positions, and conditional wages. As argued above, many of these personal characteristics have a priori ambiguous effects on the likelihood of entering and succeeding in the self-employment sector, and there is little evidence on the signs of these effects in a developing-country context. The estimated model is of the form:

$$
\begin{array}{r}
S E_{i}=1 \quad{\text { if } \alpha_{1} \text { Age }_{i}+\alpha_{2} \text { Educ }_{i}+\alpha_{3} \text { Married }_{i}+\alpha_{4} \text { Labor }_{i}+\alpha_{5} \text { Empsize }_{i}} \\
+\alpha_{6} \text { Wage }_{i}+\alpha_{7} \text { Sector }_{i}+\alpha_{8} \text { State }_{i}+\alpha_{9} \text { Year }_{i}+\varepsilon_{i}>0
\end{array}
$$

\section{(1) $S E_{i}=0 \quad$ otherwise}

where $S E$ takes the value 1 if individual $i$ becomes self-employed between the initial and the final ENEU interview and 0 otherwise, Age is a vector of categorical variables for various age ranges, $E d u c$ is a set of dummy variables that represent individuals' levels of schooling, Married is a dummy variable for married individuals, and Labor represents a vector of variables that describe individuals' labor market status, including whether they are out of the labor force, unemployed, or working. The vector Labor also describes whether inactive individuals are studying or not; whether the unemployed have been in that status for one, two, or more quarters; and whether those who are working are doing so for a salary, as contract workers, as workers without pay, or in some other modality (for example, through cooperatives). When the estimation is performed using only the sample of salaried workers, the variables Empsize and Wage are added to represent the size of the firm for which they worked at the time of the initial ENEU interview and their monthly salary in that firm. All specifications include sector dummy variables (for those who are employed), as well as state and year dummy variables, and a random error term. ${ }^{6}$

A maximum likelihood two-stage probit model with selection correction is also estimated for the determinants of entering self-employment conditional on an individual having left an initial labor market position. This approach is motivated by the fact that some personal characteristics may have a different effect on the probability of an individual changing labor market positions and entering self-employment conditional on having changed positions. Thus, for instance, unemployed workers could have a larger nonconditional probability of entering self-employment than their salaried counterparts, but it could be driven by the larger turnover rate among unemployed individuals and not by a larger conditional probability of entering self-employment-only 12 percent of the unemployed remain in that status after one year compared with almost 68 percent for salaried workers. Thus, this second estimation approach has the purpose of testing the robustness of the probit results with respect to the critique that they could be driven by the larger turnover of disadvantaged workers. 
Incidentally, this critique could also apply to Evans and Leighton's (1989, p. 58) probit result that individuals "who have changed jobs frequently" have a higher likelihood of entering self-employment. ${ }^{7}$

The first stage estimates the probability of changing labor market status between the initial and the final survey interview. The second stage, for individuals who did change labor market status, estimates the probability of entering self-employment while controlling for possible correlation between the error terms of the first- and second-stage models. The right-side variables are the same as those in equation (1), for both the first- and the second-stage equations, but added to the first-stage selection equation to identify the model is a dummy variable for individuals who have migrated to different municipalities or states; indicator variables for the second, third, and fourth quarters of each year; and dummy variables for the 99 industry groups in the Mexican classification of economic activities. ${ }^{8}$

Two data sets are used to explore the personal and firm characteristics associated with survival and growth of employment in the self-employment sector: the first comprises all self-employed individuals covered in the ENEU data set and the second a sample restricted to those in the linked ENEUENAMIN data set. While smaller, the second sample has the advantage of providing information not only on age, educational attainment, marital status, earnings, and firm size but also on capital stocks, access to credit, and time in business. When ENAMIN data are used to estimate the impact of these variables on survival and growth in self-employment, firms for which unpaid workers represent more than 50 percent of total employment are excluded.

A probit model is used to estimate the determinants of staying in self-employment, and a simple ordinary least squares estimator is used to study the correlates of microenterprise growth. The estimated model in the case of firm survival is of the following form:

$$
\begin{aligned}
\text { Survival }_{i}= & 1 \text { if } \beta_{1} \text { Age }_{i}+\beta_{2} \text { Educ }_{i}+\beta_{3} \text { Married }_{i}+\beta_{4} \text { Earnings }_{i} \\
& +\beta_{5} \text { Size }_{i}+\beta_{6} \text { Time }_{i}+\beta_{7} \text { Capital }_{i}+\beta_{8} \text { Credit }_{i}+\beta_{9} \text { Sector }_{i} \\
& +\beta_{10} \text { State }_{i}+\beta_{11} \text { Year }_{i}+\varepsilon_{i} \\
& >0
\end{aligned}
$$

Survival $_{i}=0$ otherwise

where Survival takes the value 1 if individual $i$ remains self-employed between the initial and the final ENEU interviews and 0 otherwise, Earnings represents the net

7. It must be noted, however, that the robustness check does not correct for the lack of information on the turnover of salaried workers within the salaried sector. Thus, as pointed out by one referee, in the sample of workers who changed labor market position, the salaried sector is excluded from the possible end-points of workers that begin in that sector, whereas it remains an important potential destinationrelative to self-employment-for other types of workers, such as the unemployed.

8. Changes in labor market position are found to be more likely for individuals with a migration history and in the third and fourth quarters of the year. 
monthly income from self-employment, Size is a set of dummy variables that represent the employment size of the corresponding microenterprise, Time is the number of years during which it has been in business, Capital is the value of the firm's capital stock, and Credit is a vector of variables representing whether the firm received credit from formal or informal sources, either when starting up or later. The variables Age, Educ, and Married are defined as before and so are the sector, state, and year dummy variables, which are included in all specifications.

A very similar model, with the same explanatory variables, is estimated for employment growth:

$$
\begin{aligned}
\text { Growth }_{i}= & \gamma_{1} \text { Age }_{i}+\gamma_{2} \text { Educ }_{i}+\gamma_{3} \text { Married }_{i}+\gamma_{4} \text { Earnings }_{i} \\
& +\gamma_{5} \text { Size }_{i}+\gamma_{6} \text { Time }_{i}+\gamma_{7} \text { Capital }_{i}+\gamma_{8} \text { Credit }_{i} \\
& +\gamma_{9} \text { Secto }_{i}+\gamma_{10} \text { State }_{i}+\gamma_{11} \text { Year }_{i}+\varepsilon_{i}>0
\end{aligned}
$$

where Growth is the rate of employment growth of the firm owned by the selfemployed individual $i$. This equation was also estimated simultaneously with a first-stage model of selection into the sample of microenterprises that remain in business over the one-year period during which firm growth is being measured. These results are not reported as they are virtually identical to those obtained by the simpler method described above. ${ }^{9}$

\section{Empirical Results}

Figure 1 shows the size of the self-employed sector in Mexico relative to that in other developing and advanced countries. What is immediately apparent is that Mexico has a large share of its work force in self-employment, although it is not particularly larger than would be predicted for a country of its level of development. ${ }^{10}$ Although it may be that high levels of labor market distortion or poor regulation are correlated with underdevelopment and give rise to the large sector size, for several reasons, it seems more likely that it is the lower opportunity cost of entering a desirable sector, self-employment, that drives it.

First, Blau (1987) argues that this negative correlation of self-employment with development appears clearly in the United States over the century preceding the 1970s as well as in France, the Federal Republic of Germany, Italy, and Japan because of the emergence of economies of scale and specialization of labor possible only in relatively large enterprises. Consistent with this view and Maloney's (2004) estimates based on figure 1, relative total factor productivity

9. Models were also estimated that control for possible attrition biases associated with the fact that not all the individuals could be linked across the ENEU surveys. Once again, this correction leads to virtually no changes in estimation results.

10. Some care is in order in interpreting figure 1. First, it is drawn from surveys of differing degrees of coverage of rural and urban areas. Among surveys that were only urban were those in Argentina, Bolivia, Colombia, Mexico, Paraguay, and Uruguay or roughly half of the Latin American and Caribbean data set. The data from the OECD are economy-wide, but the share of the work force in rural areas is quite small. 
Figure 1. Self-Employment and Industrial Productivity

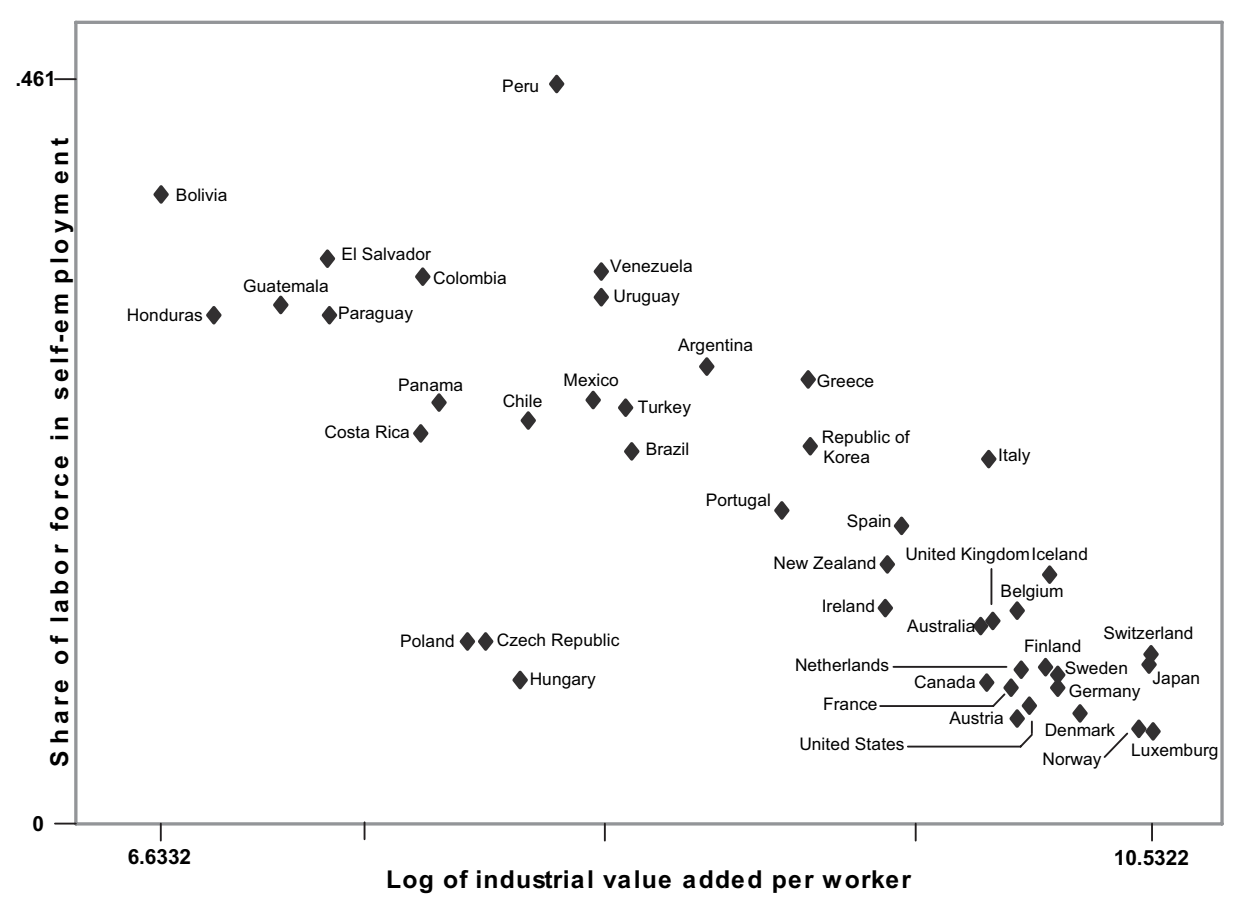

Source: Authors' calculations using household surveys from the mid-1990s and World Bank Institute data.

emerges as statistically important, explaining the long-term secular decline as well as the rise in self-employment after the mid-1970s.

Second, although Blanchflower (2004) documents that self-employment is risky and stressful, as noted earlier, Blanchflower and Oswald (1998) also note that 63 percent of salaried workers in the United States, 48 percent in the United Kingdom, and 49 percent in Germany report that they would prefer to be selfemployed, a fraction similar to the more than 60 percent of Mexican entrants to self-employment who report doing so voluntarily (see Maloney 1999). Furthermore, Blanchflower (2004) reiterates the robust finding that those who enter self-employment report higher levels of job satisfaction than employees. The fact that industrial country workers do not actually pursue their desire to become self-employed may reflect, again, the higher opportunity cost of doing so.

Finally, and consistent with the documented heterogeneity of the microenterprise sector, there is clearly room for segmenting labor market distortions or other regulatory distortions to drive sector size as well, although it is not yet clear how large a role these play. As a crude first pass, the celebrated difference in social models in France and the United States leads to no difference in the share of the work forces in self-employment in the two countries. That said, 
Blau (1987) does find rising marginal income tax rates, along with rising total factor productivity in self-employment, to drive the U.S. increase in male selfemployment, from 10 to 13 percent across the decade of the 1970s. Antunes and Centeno (2005) find that higher labor flexibility in the OECD countries decreases the probability of entry into self-employment, although they do not offer an impact on sector size. Maloney (2001), explaining the variance in figure 1 , and Loayza, Oviedo, and Serven (2005), explaining cross-country variance in levels of informality more generally, find statistically significant impacts of labor regulation, but the level of development plays a much larger explanatory role. ${ }^{11}$

Table 1 succinctly summarizes the structure and dynamics of the Mexican labor market. In addition to summarizing the breakdown of self-employment by the number of workers of the corresponding firms, Table 1 describes the composition of the Mexican labor force by employment status (e.g. self-employment, salaried work, and unemployment). The table includes a separate category for the aggregate of self-employed individuals (regardless of firm size). The lower panel shows the probabilities of transitioning across different labor market statuses. Rows represent individuals' initial labor market positions and columns their labor market statuses one year later. Each cell shows the percentage of individuals who start in a given row category and end in the corresponding column category.

If the United States is taken as a benchmark, the rates of entry and exit into self-employment in Mexico are of very similar orders of magnitude. Mexican entrepreneurs are slightly more likely to return to wage work-at a rate of 15 percent compared with 13.8 percent reported by Evans and Leighton (1989) for the United States. A slightly higher fraction of Mexican wageworkers enter self-employment: 6.2 percent compared with 4 percent a year found by Evans and Leighton, and perhaps this leads to a poorer selection of entrepreneurs at the margin, as Hopenhayn (1992) suggests. Note, however, that because in the steady state, workers exiting self-employment must be replaced each year by the same number of new entrants, the higher rate of entry into self-employment from the wage sector that is found in Mexico is partly because of the relatively smaller size of the wage sector there.

Table 1 also summarizes that many microentrepreneurs originate and move to labor market positions other than salaried work. Thus, for instance, 12.4 percent of contract workers enter self-employment in a given year-twice the fraction of their salaried counterparts - and so do 11 percent of the unemployed. Moreover, although 15 percent of the self-employed move to salaried work during a given year, the same number of individuals migrates to other labor market positionsto contract work (6.2 percent) and out of the labor force (5.7 percent). As for microenterprise growth, table 1 reveals that very few microenterprises are able to expand their employment, at least over one-year periods. As an example, only

11. Antunes and Centeno (2005) also find regulation issues affecting the transition into and out of self-employment in OECD countries but do not follow through on the implications for sector size. 


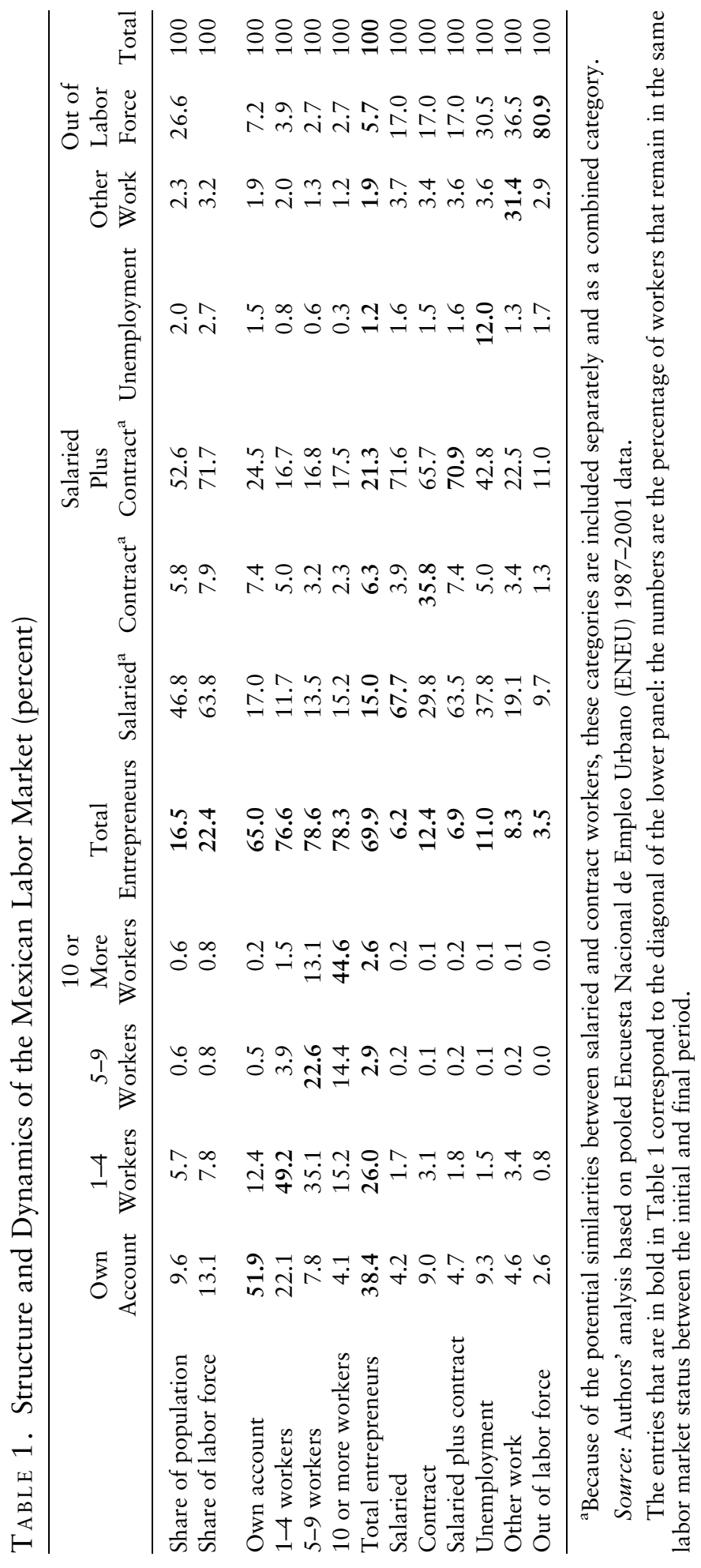


13.1 percent of microentrepreneurs with five to nine employees exhibit any expansion (to having at least 10 workers), 22.6 percent remain in the same size range, and 42.9 percent report a reduction in the number of employees. Own-account workers have similar rates of expansion, offset by a substantial decrease in employment among firms with one to four workers.

Figures 2 and 3 show respectively for Mexico and the United States, by age group, the fraction of the labor force in self-employment, the rate of entry from salaried work into self-employment, and the rate of exit from self-employment. Broadly consistent with figure 1, the self-employment rate in Mexico is at least twice as high as in the United States in every age group. The overall age patterns of self-employment rates as well as those of entry and exit are strikingly similar in the two countries. As a foreshadowing of the more detailed exercises below, the common upward and downward sloping relationships of age with rates of entry and exit are consistent with the view that older entrepreneurs get a more precise view of their underlying entrepreneurial capacity and are more likely to enter and less likely to fail than younger individuals.

\section{Patterns of Entry}

Table 2 presents the results of a more systematic examination of patterns of entry into self-employment. Columns 1-3 report probit estimates of a model of

Figure 2. Patterns of Entry and Exit into Self-Employment in Urban Mexico

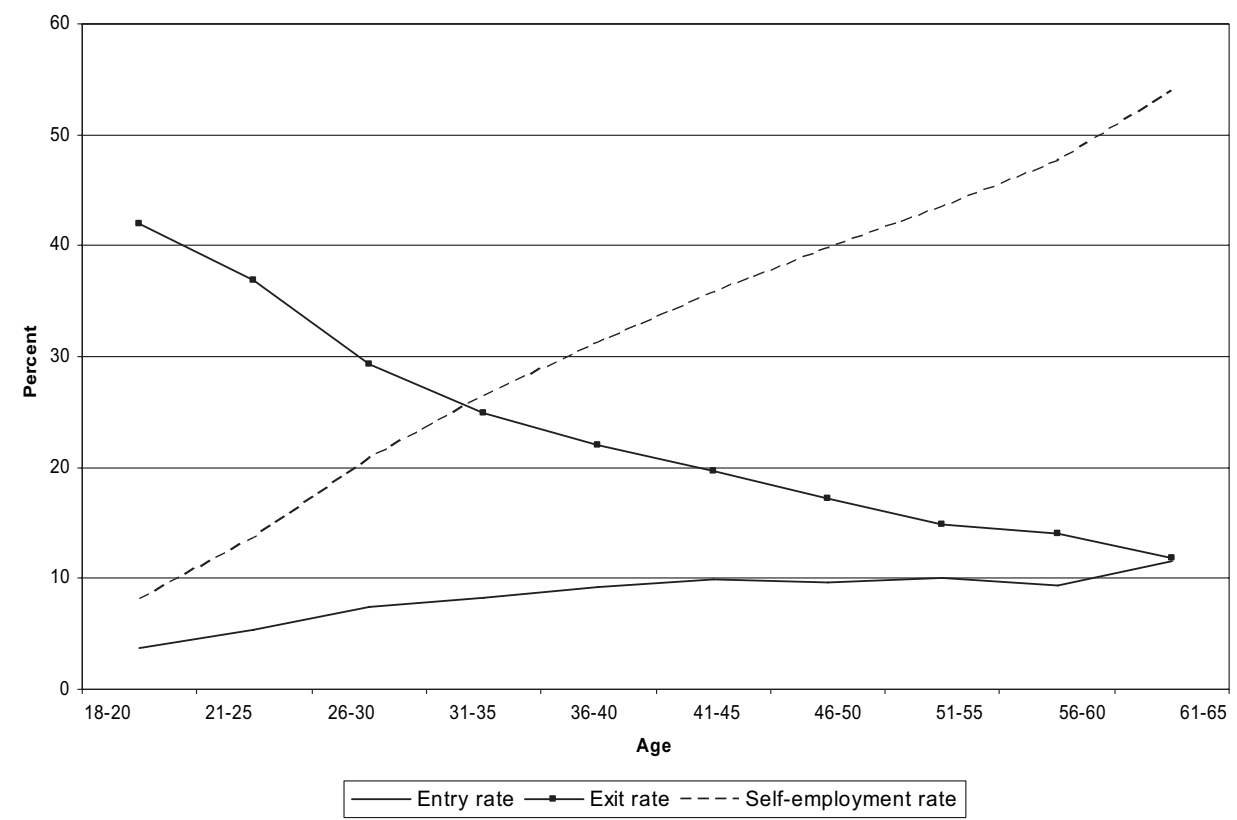

Source: Authors' calculations using Encuesta Nacional de Empleo Urbano (ENEU) data. 
Figure 3. Patterns of Entry and Exit into Self-Employment in the United States

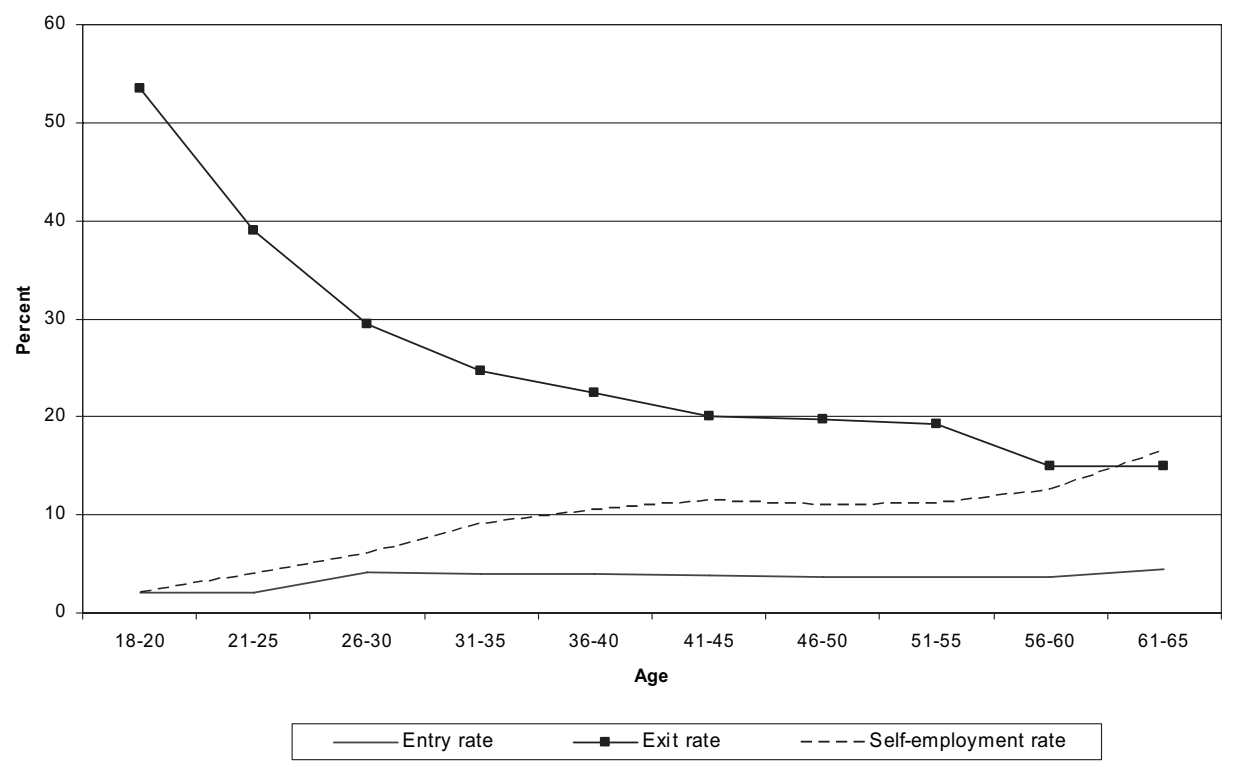

Source: Evans and Leighton (1989).

the determinants of becoming self-employed over a one-year period, as measured in the final ENEU interview. It uses a sample that excludes all individuals who were self-employed in the initial ENEU interview and includes both activealthough not self-employed-and out of the labor force individuals. Columns 4-6 report probit estimates of a similar entry model by using a restricted sample of individuals who were salaried workers at the time of the first ENEU interview. While the reported results are obtained without differentiating those who enter self-employment with or without employees, similar models were also estimated that define entry more restrictively as the act of becoming self-employed with at least one employee. With a few exceptions (discussed below) the results are substantially similar to those obtained with the broader definition of self-employment.

Columns 1 and 4 present standard probit estimates of the effects of personal characteristics on the probability of entering self-employment for the wider sample of all non-self-employed individuals and for the sample of salaried workers. Rather than probit coefficients, the two columns report marginal changes in the probability of entering self-employment resulting from discrete changes in the independent dummy variables and from infinitesimal changes in the only 


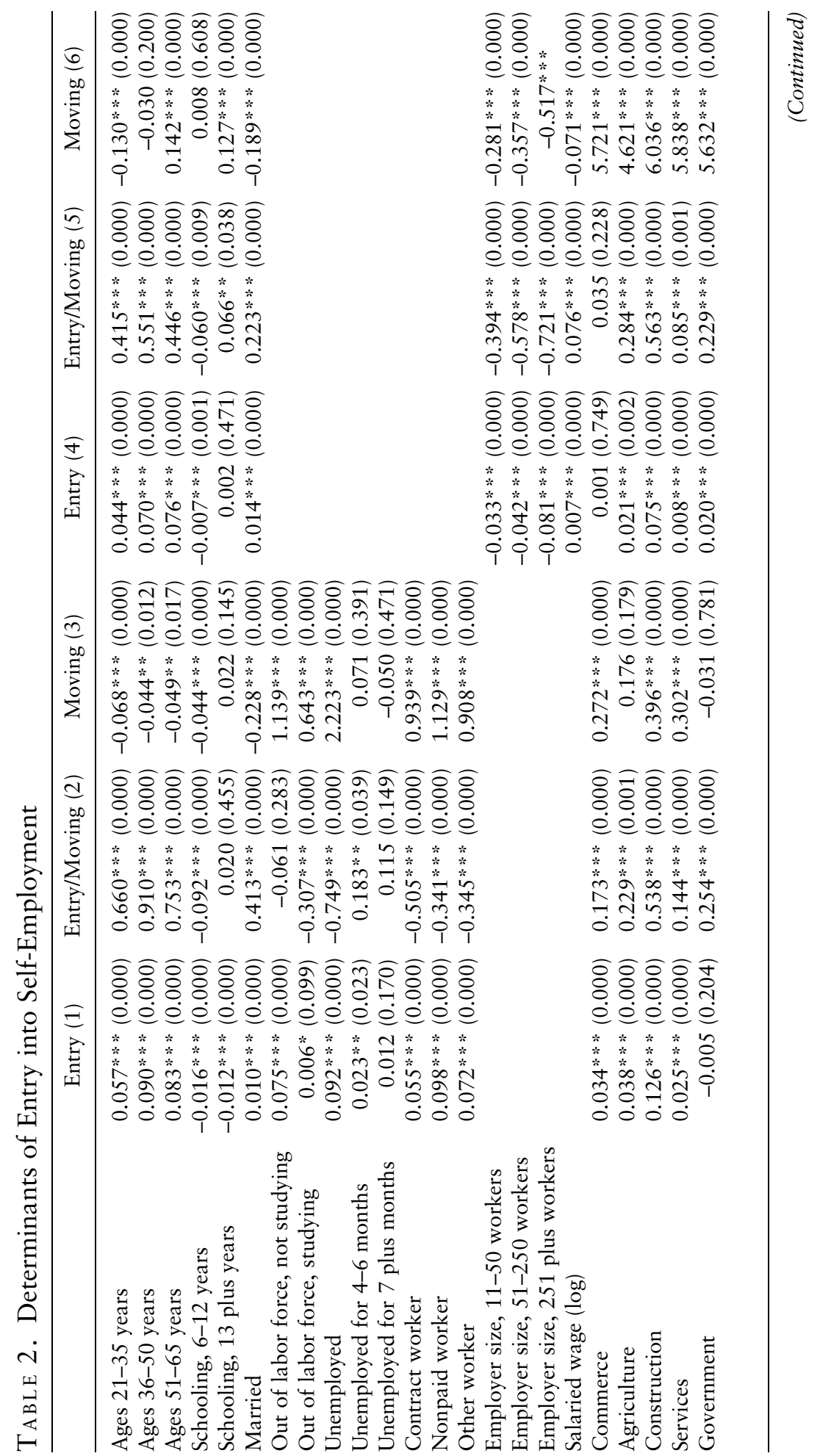




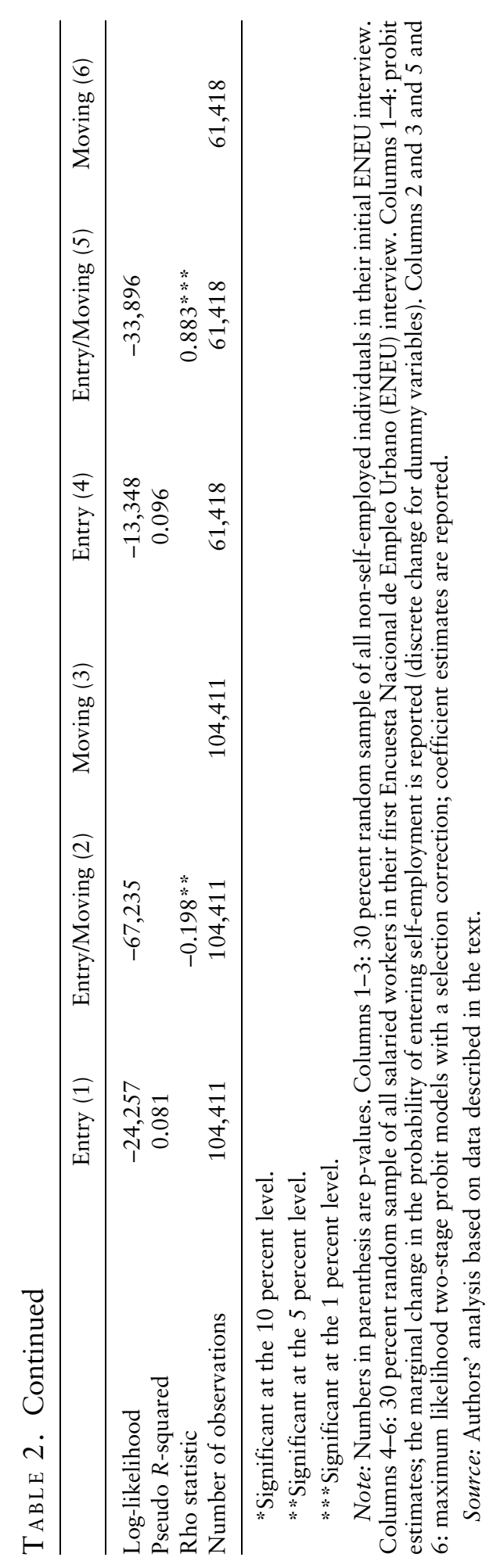


continuous explanatory variable (Wage). Columns 2 and 5 report the results of probit models estimated for restricted versions of the samples of all non-selfemployed and all salaried workers, keeping only individuals who changed labor market status between the first and second ENEU interviews. These equations are estimated simultaneously with first-stage probit models of the determinants of changing labor market status between the two interviews, for which results are reported in columns 3-6. (Columns 2, 3, 5, and 6 report coefficient estimates.)

A clear age pattern emerges across specifications and samples reflecting the rising likelihood of entry until the 36-50 age bracket. Thus, keeping other personal characteristics constant and comparing with individuals aged 15-20 years (for which the rate of entry into self-employment is 2.4 percent; not shown in the table), the probability of entering self-employment is 5.7 percentage points higher for those aged 21-35 years and 9 percentage points higher for those aged 36-50 years. Although the corresponding increases in the probability of entering selfemployment are slightly smaller in the sample of salaried workers (column 4), the findings are not consistent with the view of the sector as a point of entry into the labor market. They are, however, consistent with the U.S. data, Evans and Jovanovic's (1989) liquidity constraints hypothesis, and the view that older workers have a more precise measure of their underlying entrepreneurial capacity.

Educational attainment has a negative, if quantitatively small, effect on the probability of entering self-employment. Thus, while the average worker with at most some primary education has a 10.3 percent probability of entering selfemployment, similar workers with some secondary education have 1.6 percentage points lower entry probability and those with some tertiary education a 1.2 percentage points lower probability (table 2, column 1). However, when restricting the sample to salaried workers (column 4) or conditioning on changing labor market status (columns 2 and 5), the negative relationship between education and entry into self-employment levels off and breaks up at higher levels of schooling, suggesting that college graduates may find the sector attractive. Moreover, when the definition of self-employment is restricted to business owners who employ at least one worker, both secondary and tertiary schooling are positively linked to entry into self-employment. This result is broadly consistent with Evans and Leighton (1989), Carrasco (1999), and Rees and Shah (1986), who found that entry rises monotonically with education.

Also consistent with Rees and Shah (1986) and Carrasco (1999) is the finding that being married is positively associated with entry, which may reflect either that the sector is not riskier than alternatives available in the labor market (salaried employment) or that being married helps diversify risk. Quantitatively, marriage has the effect of increasing by 1 percentage point the probability of entry into self-employment, which is 4.5 percent on average for nonmarried individuals. Because, as columns 3 and 6 suggest, married men are less likely to 
change their initial labor market status, the effect of marital status is much stronger-about four times as large-for conditional estimates.

The importance of conditioning on changes in labor market positions becomes most clear in looking at the impact of initial employment and labor force participation status. The unconditional results suggest that individuals out of the labor force and not studying and those unemployed are more likely to enter self-employment, consistent with traditional dualistic views of the sector as disguised unemployment. Thus, while the rate of entry is 6.2 percent for the average salaried worker, the probability of entry increases for individuals who have been unemployed, for nonpaid workers, for those who are out of the labor force and not studying, for contract workers, and for other types of workers (table 2, column 1).

However, as column 3 shows, these are also labor market positions with very high rates of turnover; so, workers may well be more likely to move to all sectors at disproportionately high rates. After conditioning on changing labor market status, unemployed and nonsalaried workers (contract or nonpaid workers) are less likely to enter self-employment than those in formal salaried employment. Put differently, given that a worker will change an initial labor market position, those in formal salaried employment are more likely than most other groups to enter informal self-employment. It is worth noting, however, that among the unemployed, workers with longer unemployment spells-especially those who have been unemployed for four to six months-have higher conditional and unconditional probabilities of entering self-employment. This suggests that, even if the sector does not function predominantly as a holding pattern for misfits or those rationed out of salaried work, it does offer income opportunities for the long-term unemployed. Nonetheless, those opportunities appear to be associated with opening businesses that are owner-only, as estimates of the probability of opening microenterprises with at least one worker show nonsignificant effects for the duration of unemployment. ${ }^{12}$

The final three columns of table 2 present estimates for the sample of salaried workers and suggest two perhaps contradictory effects of firm size and earnings. While salaried workers employed in firms with at most 10 employees have a 12.8 percent probability of entering self-employment, that probability diminishes by between 3.3 and 4.2 percentage points for those coming from firms with 11-250 workers and by 8.1 percentage points for those previously employed in firms with more than 250 employees. This finding may be because of nonpecuniary benefits (such as social security) and job stability offered by larger firms. That the same pattern emerges conditionally although workers in larger firms are significantly less likely to change labor market position-the

12. The other results obtained with the more restrictive definition of self-employment are generally similar to those reported in this article. 
negative effect of firm size is only slightly reduced in the results reported in column 5-might suggest that the results are capturing the impact of unmeasured firm- or sector-specific human capital. However, conditional on firm size and individual characteristics, workers with higher conditional wages are more likely to start a microenterprise. Whether this reflects a relaxation on the liquidity constraint or entrepreneurial ability cannot be known at this point. However, the finding that overperformers in the salaried sector are more likely to enter self-employment is at odds with predictions of both the dualistic approach to the sector and the sociological view of the sector as a preferred destination for misfits.

Sector of economic activity also has an impact. Entry into self-employment is most likely for those who hold jobs in the construction sector, and it is least likely for those employed in manufacturing. Thus, whereas a salaried worker in manufacturing has a 4.3 percent probability of entering self-employment, the probability for a salaried construction worker with similar personal characteristics is 7.5 percentage points higher (table 2, column 4). Salaried workers with jobs in agriculture and government also have-probably for different reasons-a higher probability of entering self-employment than their counterparts in manufacturing.

\section{Who Survives?}

The determinants of firm survival are estimated using a probit specification that links individual and firm characteristics to the probability of staying in selfemployment over a one-year period (table 3$).{ }^{13}$ The sample is restricted to individuals who reported that they were self-employed in the first ENEU interview. Data from both the larger ENEU sample (column 1) and the smaller ENAMIN-ENEU-linked database (columns 2-4) are used to capture more firm-specific characteristics.

The age patterns shown in figure 2 are confirmed with the probability of survival increasing with age until the $36-50$ age bracket (column 1 ). The average self-employed individual in the age bracket $15-20$ years has a 33.3 percent probability of staying self-employed, whereas for individuals with similar personal characteristics, the probabilities of survival are 18.7 percentage points higher in the 21-35 bracket and 27.2 percentage points higher in the 33-50 bracket. A similar age pattern, although with smaller increases in survival derived from age alone, is found when the same specification is estimated with the smaller albeit richer ENAMIN-ENEU sample (columns 2-4).

13. The results are subject to the caveat that we cannot observe whether self-employed individuals are still running the same businesses as in their initial interviews. Thus, in practice, the estimate is of the determinants of an individual staying in self-employment, as opposed to the determinants of an enterprise staying in business. To the extent that failed entrepreneurs tend to switch to a different labor market position before moving to a new business venture, the above assumption should have a minor impact on the results. 


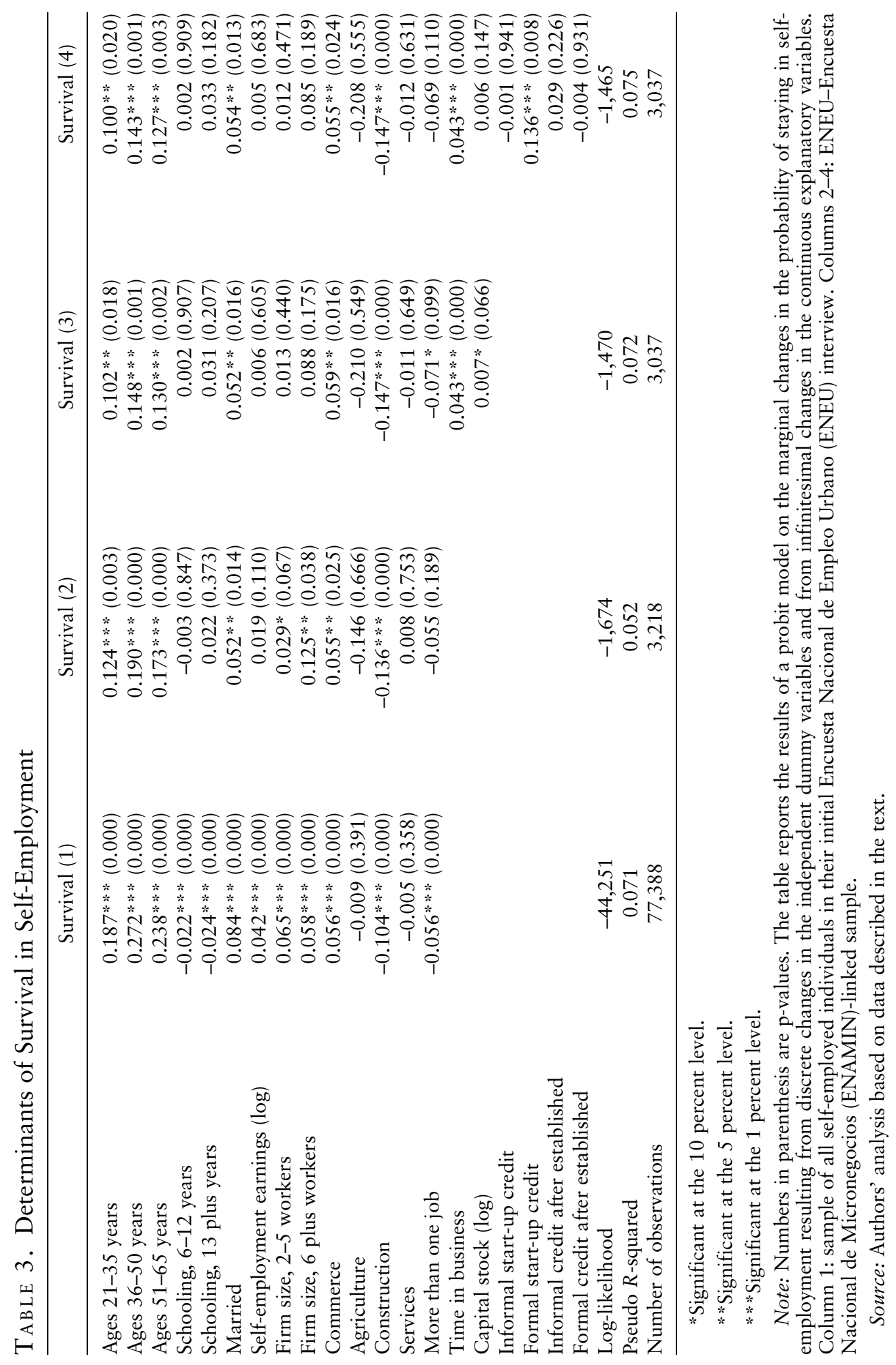


Education has a negative impact on the probability of staying in self-employment (column 1). However, this effect is quantitatively small, with a reduction of about 2 percentage points in the survival probability for individuals with secondary or tertiary schooling compared with a 70 percent probability of staying for those with at most primary schooling, and it disappears in the smaller sample. These results seem counterintuitive in that more educated workers would seem better able to evaluate the probability of success in potential business opportunities and also to do better in business, as suggested by Bates (1999). In fact, when the sample is restricted to self-employed individuals who report at least one worker, the effect of educational attainment on firm survival becomes positive and significant, especially for those with some college education. As for the larger sample that includes owner-only businesses, to the degree that better-educated workers may find better opportunities in the formal sector, this may be the effect of a higher "pull" effect of better employment alternatives for more educated individuals dominating a lower "push" effect associated with smaller probabilities of business failure.

However, consistent with the relevance of this effect and the various mainstream models of firm dynamics reviewed above, higher conditional wages lead to a higher probability of survival. Thus, using the larger sample and including all self-employed individuals regardless of whether they have employees, a doubling of the earnings from self-employment is associated with a 4.2 percentage point increase in the probability of staying in that sector. The effect is quantitatively larger when the sample is restricted to businesses with at least one employee, for which a doubling of self-employment earnings is related to an 8.8 percentage point increase in the probability of maintaining that initial status.

Firm size is also positively and significantly related to survival in selfemployment in both the larger and the restricted sample, which is consistent with the predictions of mainstream firm dynamics models. ${ }^{14}$ However, when time in business and capital stocks are also controlled for using the smaller ENEU-ENAMIN sample (table 3, column 3), the variables representing employment size and age of the entrepreneur cease to be significant, suggesting that they were merely proxying for the former variables, which do exhibit significant effects on self-employment survival. In particular, a doubling of the time that a microenterprise has been in business is associated with a 4.3 percentage point increase in its likelihood of survival, whereas a tripling of its capital stock is related to a 1.4 percentage point increase. Taken together, the results are quite consistent both with Jovanovic's (1982) “noisy selection" view and with the bulk of the mainstream empirical evidence that firms get a more precise estimate of

14. In the larger ENEU sample, the effect of having at least one employee is that of increasing by about 6 percent the probability of survival in self-employment. In the smaller ENEU-ENAMIN sample, the increase is smaller for those with at most five workers (2.9 percent) than for firms with at least six workers including the owner (12.5 percent). A similar increase (13 percent) is obtained for firms with at least six employees when the sample is further restricted to firms with at least one employee. 
their cost structures with experience and that past measures of success are informative for the future evolution of the firm.

Survival in self-employment is 5-8 percentage points higher for married individuals, possibly because they can count on unpaid family workers, and those who report a second job are about 6 percentage points less likely to remain in self-employment. Moreover, self-employed workers in the construction sector have a probability of staying in self-employment that is 10-15 percentage points lower than for those engaged in agriculture, manufacturing, or services, whereas the self-employed workers engaged in commercial activities have a 5.5 percentage points higher survival probability than their peers in the above three sectors.

Finally, access to formal credit at start-up seems to affect whether firms survive, consistent with Evans and Jovanovic's (1989) view: firms with access to credit exhibit a 13.6 percentage points higher probability of survival than their peers with similar owner and enterprise characteristics (table 3, column 4). Once firms are established, however, neither formal nor informal channels of credit have a significant effect on survival in self-employment. However, because credit variables are positively correlated with unobservable characteristics of the firm that also affect the prospects of firm survival and growth, these estimates should be interpreted with caution. Thus, for instance, the presence of unobserved heterogeneity in managerial ability, not captured by conditional selfemployment earnings and positively related to access to credit, could upwardly bias the impact of access to credit on firm survival. Moreover, the bias could also go in the opposite direction if some covariates already embody effects derived from credit access (for example, higher capital stock, employment size, and time in business). Provided that sensible instruments for credit access can be generated, future research should further explore the importance and direction of those possible estimation biases.

\section{Growth}

Employment growth is somewhat difficult to analyze because the aggregate categorical employee coding of the ENEU prohibits direct comparisons of employment dynamics with those of the United States. However, the transition matrix in table 1 suggests that, as in the United States, microenterprises create relatively more jobs but destroy roughly equivalent numbers and generate little net job creation. Individuals starting microenterprises have a higher probability of simply remaining self-employed than of increasing their firm size, whereas a firm with more than one employee has a higher probability of decreasing its size than of increasing it. Only 12 percent of owner-only firms expand to one to four employees, whereas 22.1 percent of firms of one to four employees contract to owneronly. The share of firms that go out of business decreases with firm size and ranges from 35 percent for owner-only to 22 percent for the largest category.

These dynamics are broadly consistent with a steady-state distribution dominated by very small firms. Again drawing on the United States as a benchmark, 
the overall size distribution of microenterprises in Mexico is similar in terms of owner-only firms. According to U.S. Small Business Administration and Census Bureau data, 67 percent of registered U.S. firms are owner-only, and another 12 percent have at most five workers, including the owner. ${ }^{15}$ In Mexico, 62 percent of businesses operated by the self-employed have no employees, and 32 percent have at most five workers. ${ }^{16}$ Although Mexico and the United States are clearly different at the upper tail of the size distribution, at the lower tail, both the countries exhibit a remarkably large and similar share of owner-only firms.

The larger absolute number of small firms may reflect simply that, as the opportunity cost of starting a small firm falls, more workers enter, the relative distribution of ability remains similar or, in line with Hopenhayn's (1992) argument, falls, leading, in line with Lucas's (1978) insight, to a large share of very small firms. Alternatively, barriers to credit or other services may keep firms below their optimal size, a hypothesis investigated briefly later and in more detail in Fajnzylber, Maloney, and Montes Rojas (2006). The fact that most U.S. microenterprises, which exist in a relatively well-functioning economic environment, also remain very small does, perhaps, lend support to the first hypothesis.

The analysis also examines what characteristics seem correlated with a transition between size brackets over a one-year period, considering only surviving firms. ${ }^{17}$ The dependent variable is the imputed percentage difference between the mean value of employment in the corresponding firm size brackets. By definition, firms that remained in the same size interval have a value of zero. The results are summarized in table 4, with the results for the full ENEU sample presented in column 1 and the results for the smaller joint sample presented in the other three columns.

The relationships between firm growth and the age and marital status of the entrepreneurs are broadly similar, at least in the large sample estimates, to those obtained in the survival analysis: business owners who are married and in the age bracket 36-50 years are most likely to expand their firms, exhibiting employment growth rates that are, respectively, 11.1 and 9.4 percentage points higher than those of their peers. ${ }^{18}$ Consistent with mainstream models, entrepreneurs with conditionally higher earnings (better performance) seem to show a higher

15. Authors' calculations using U.S. Small Business Administration (2001).

16. Authors' tabulations based on the Mexican National Urban Employment Survey (ENEU). It is worth noting that while self-employment rates hover between 5 and 15 percent in most OECD countries, Latin America exhibits rates that are generally between 20 and 35 percent (figure 1). Even within the OECD, as reported by Blanchflower (2004, p. 10), "self-employment rates are generally higher in poorer countries."

17. Firm size is divided into owner-only firms, 2-5 employees, 6-10 employees, 11-15 employees, 16-50 employees, 51-100 employees, 101-250 employees, and 250 and more employees.

18. While the positive sign encountered in the marital status variable may well reflect the use of nonpaid family workers, the results are virtually unchanged when the firms with mostly nonpaid workers are kept in the sample. 


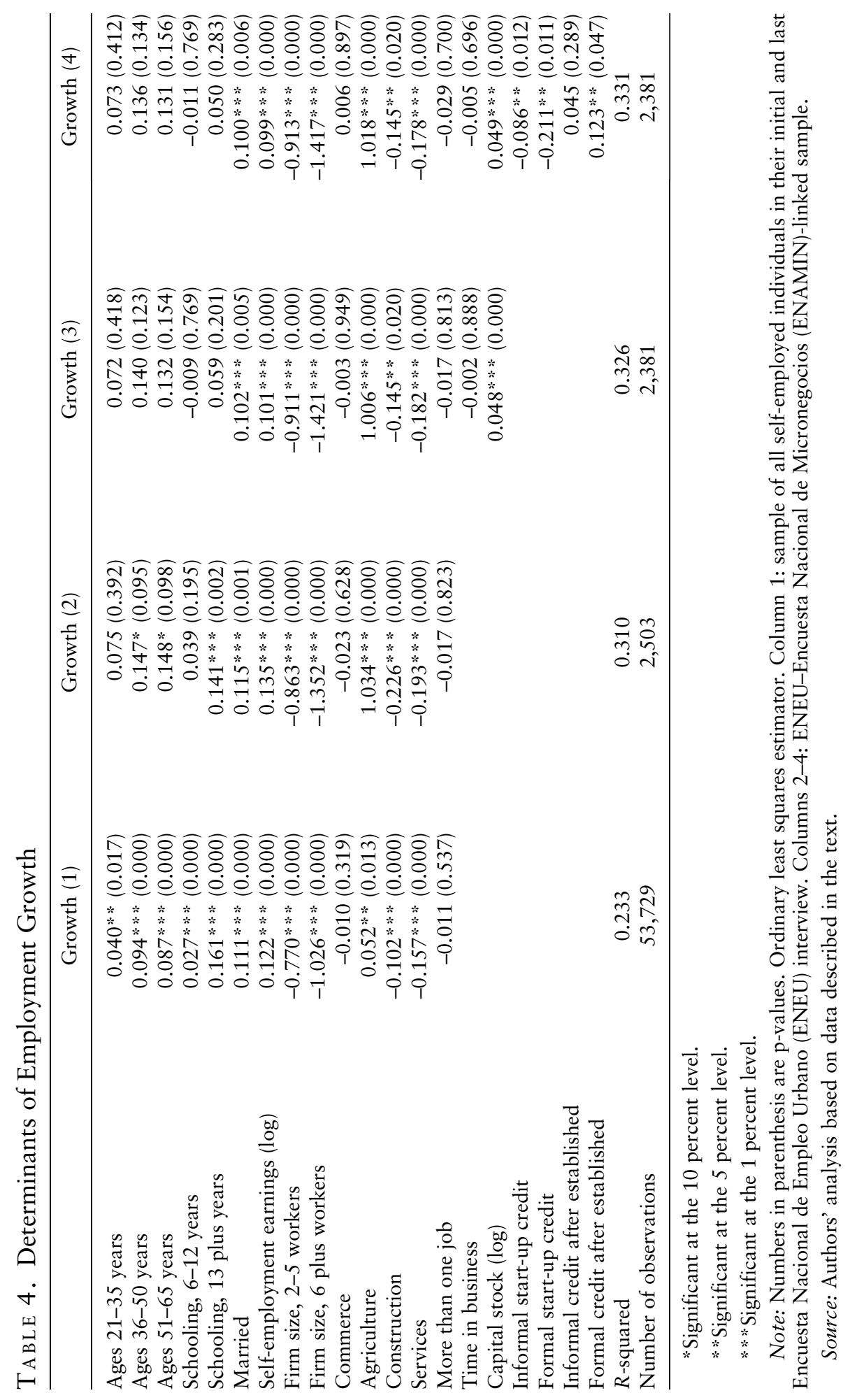


propensity to grow. Moreover, the educational attainment of the owner now has a positive and significant effect on firm growth, at least when detailed firm characteristics are not controlled for.

Given that the estimates are conditional on surviving, firm size appears with the negative sign predicted by the mainstream literature: bigger firms are more likely to have achieved their optimal size. Time in business also has a negative effect, as expected from the literature on industrial countries, but its coefficient is not statistically significant. Similarly, consistent with Ericson and Pakes (1989, 1995), although less so with Evans and Jovanovic (1989), higher capital stocks are positively correlated with employment growth.

The effect of credit variables depends on the type of credit and whether it was granted at start-up or afterward (table 4, column 4). Consistent with Evans and Jovanovic (1989), the lack of access to start-up credit may imply suboptimal start-up size, with more rapid subsequent growth compared with firms that started closer to their steady-state size. This does not contradict the finding that formal sector loans granted at a later stage, when firms may be closer to their steady state and entrepreneurs better able to reveal their managerial ability, have a positive and significant impact on growth. Again, endogeneity issues urge circumspection and more careful future research.

\section{Conclusions}

This article has documented patterns of entry, survival, and growth in the Mexican self-employment sector. The results suggest that the Mexican selfemployment sector is much larger than its counterpart in the United States, which is reflected in higher unconditional rates of entry. Moreover, the evidence points to the significant presence of well-performing salaried workers among the likely entrants into self-employment in Mexico, as opposed to the higher incidence of poorer wageworkers among the entrants into the U.S. selfemployment sector. Despite these differences, however, the evidence for Mexico is very similar to that for the United States in terms of patterns of entry, survival, and growth with respect to age, education, and many other covariates. As a first approximation, microenterprises in Mexico show dynamic patterns consistent with the entrepreneurial risk-taking view usually applied to firm dynamics in the industrial world. In particular, the noisy selection and learning by doing theoretical features seem to be consistently corroborated in the sample estimates.

The patterns of entry into self-employment show that even if liquidity constraints are important for determining the future performance of new firms, self-employment does not appear to be less desirable than other labor market alternatives. Indeed, once the analysis is conditioned for the probability of changing labor market status, salaried workers are more likely to enter selfemployment than individuals who are unemployed or out of the labor force. 
Moreover, there is evidence that being employed as a salaried worker in a larger firm reduces the probability of entry-presumably because of benefits and job stability-but once the analysis is conditioned for firm size, higher wages increase the likelihood of becoming a microentrepreneur. This result runs counter to the view of self-employment as a holding pattern for misfits or workers rationed out of the salaried sector but supports the hypothesis that unobserved ability plays a crucial role in selecting workers in and out of selfemployment.

The results on firm survival and growth also confirm the relevance of mainstream models, with size and time in business being negatively related to exit and growth. Moreover, while concerns regarding the possible endogeneity of variables related to access to credit must be kept in mind, receiving a loan after having started a business is associated with higher odds of growing, whereas receiving a loan at the time of start-up is associated with lower rates of both exit and employment growth. Presumably, this is because entrepreneurs who receive loans at the time of entry achieve an optimal size sooner.

Taken together, the results suggest first that the insights of the mainstream theoretical and empirical literature are relevant to analysis of developing-country microenterprises and thus provide helpful guides to policy. Second, they suggest that, overall, the sector corresponds closely to the dynamic models of voluntary entrepreneurship described for industrial countries.

This is not to downplay the vast heterogeneity of the sector. Firms with at least one employee correspond most neatly to the mainstream literature, whereas the dominant group of own-account businesses differs in some suggestive respects. Their entry rates fall with education, and they have lower potential for growth in response to conditionally higher earnings, suggesting that these firms may be relatively less "dynamic." But this is consistent with a combination of Lucas' (1978) and Blau's (1987) views, discussed earlier, in a developing-country context: very low formal sector productivity, particularly for low-skilled workers, implies a low opportunity cost for many workers of very poor entrepreneurial ability to enter the sector who may have no plans or capability to expand beyond one person. By contrast, the rising exit rates with education and higher rates of entry from unemployment may suggest, reasonably, that involuntary entrants to the sector are likely to be found among single-person firms. Nonetheless, the commonality of most covariate signs across subsamples of firm sizes, the fact that reported rates of voluntary entry, while below those of larger microenterprises are still close to 60 percent, and the procyclical pattern of gross labor flows into the sector overall (Bosch and Maloney 2005) suggest that the dominant character of the subsector is broadly in line with a mainstream view. ${ }^{19}$

19. In 1992, those reporting voluntary entry were 57.5 percent of own-account firms and 68.1 percent of firms with one employee or more. During the crisis, as might be expected, the rate of voluntary entry fell substantially in both the groups. 
ENEU variables

- Self-employment: dummy variable that takes a value of one if the individual's primary occupation is self-employment or owner of a firm.

- Age: dummy variables for individual age brackets. Base category: ages 15-17 years.

- Schooling: dummy variables for years of schooling completed. Base category: less than six years of schooling.

- Married: dummy variable for married individuals.

- Out labor: dummy variable for individuals who are out of the labor force.

- Unemployed: dummy variable for unemployed individuals.

- Unemployed for four to six months and for seven plus months: dummy variables for individuals who have been unemployed for four to six months or for at least seven months.

- Salaried wage (log): logarithm of real monthly income from main job (salaried, contract worker, and others). The bottom and top percentiles are excluded from the sample.

- More than one job: dummy variable for having an income source other than the main job.

- Self-employed earnings (log): logarithm of real monthly income from the main job (if self-employed or owner).

- Contract worker: dummy variable for contract workers.

- Nonpaid worker: dummy variable for individuals who are working without pay.

- Other work: dummy variable for paid workers in either a cooperative or other unspecified types of jobs (not salaried, not contract).

- Size of firm: dummy variable for the number of employees in the firm that corresponds to the main job.

- Employment growth: imputed percentage difference (in logarithm) between the mean value of the corresponding firm size brackets in a oneyear period. By definition, firms that remained in the same size interval have a value of 0 .

ENAMIN variables

- Capital stock: sum of the replacement cost of all owned or borrowed physical capital and the market price of all firm inventories.

- Time in business: number of years since owner began the activity or became head of the business.

- Informal credit: dummy variables for microenterprises that report receiving credit from clients, suppliers, friends, or family at the time of start-up or after.

- Formal credit: dummy variables for microenterprises that report receiving credit from a bank at the time of start-up or after. 


\section{REFERENCES}

Antunes, Antonio, and Mario Centeno. 2005. Do Labor Market Policies Affect Employment Composition? A Look at European Countries. Lisbon: Banco de Portugal.

Aw, Bee Yan, Sukkyun Chung, and Mark J. Roberts. 2003. "Productivity, Output, and Failure: A Comparison of Taiwanese and Korean Manufacturers.” Economic Journal 113(491):F485-510.

Balán, J., H. L. Browning, and Jelin, E. 1973. Men in a Developing Society. Austin: Texas: University of Texas Press.

Bartelsman, Eric, John Haltiwanger, and Stefano Scarpetta. 2004. "Microeconomic Evidence of Creative Destruction in Industrial and Developing Countries.” Policy Research Working Paper 3464. World Bank, Washington, D.C.

Bates, Timothy. 1999. "Entrepreneur Human Capital Inputs and Small Business Longevity." The Review of Economics and Statistics 72(4):551-59.

Bhattacharaya, Prabir C. 2002. "Rural-to-Urban Migration in LDCs: A Test of Two Rival Models." Journal of International Development 14(7):951-72.

Blanchflower, David G. 2004. "Self-Employment: More May Not Be Better.” Swedish Economic Policy Review 11(2):15-74.

Blanchflower, David G., and Andrew J. Oswald. 1998. "What Makes an Entrepreneur?” Journal of Labor Economics 16(1):26-35.

Blau, David M. 1987. “A Time-Series Analysis of Self-Employment in the United States.” Journal of Political Economy 95(3):445-67.

Bosch, Mariano, and William F. Maloney. 2005. "Labor Market Dynamics in Developing Countries: Comparative Analysis using Continuous Time Markov Processes.” Policy Research Working Paper 3583. World Bank, Washington, D.C.

Carrasco, Raquel. 1999. "Transitions to and from Self-Employment in Spain: An Empirical Analysis." Oxford Bulletin of Economics and Statistics 61(3):315-41.

Cressy, Robert. 1996. “Are Business Startups Debt-Rationed?” Economic Journal 106(438):1253-70.

Cunningham, Wendy V., and William F. Maloney. 2001. "Heterogeneity among Mexico's Microenterprises: An Application of Factor and Cluster Analysis." Economic Development and Cultural Change 50(1):131-56.

De Soto, Hernando. 1989. The Other Path: The Invisible Revolution in the Third World. New York: Harper and Row.

Dunne, Timothy, Mark J. Roberts, and Larry Samuelson. 1988. "Patterns of Firms Entry and Exit in U.S. Manufacturing Industries." RAND Journal of Economics 19(4):495-515.

Dunne, Timothy, Mark J. Roberts, and Larry Samuelson. 1989. "The Growth and Failure of U.S. Manufacturing Plants.” Quarterly Journal of Economics 104(4):671-98.

Ericson, Richard, and Ariel Pakes. 1989. "An Alternative Theory of Firm and Industry Dynamics." Working Paper 445. Columbia University, Department of Economics, New York.

Ericson, Richard, and Ariel Pakes. 1995. "Markov-Perfect Industry Dynamics: A Framework for Empirical Work." Review of Economic Studies 62(1):53-82.

Evans, David S. 1987a. "The Relationship between Firm Growth, Size, and Age: Estimates for 100 Manufacturing Industries." Journal of Industrial Economics 35(4):567-81.

Evans, David S. 1987b. "Tests of Alternative Theories of Firm Growth." Journal of Political Economy 95(4):657-74.

Evans, David S., and Boyan Jovanovic. 1989. "An Estimated Model of Entrepreneurial Choice under Liquidity Constraints.” Journal of Political Economy 97(4):808-27.

Evans, David S., and Linda S. Leighton. 1989. "Some Empirical Aspects of Entrepreneurship.” American Economic Review 79(3):519-35. 
Fajnzylber, Pablo, William F. Maloney, and Gabriel Montes Rojas. 2006. "Releasing Constraints to Growth or Pushing on a String? The Impact of Credit, Training, Business Associations and Taxes on the Performance of Mexican Micro-Firms.” Policy Research Working Paper 3807. World Bank, Washington, D.C.

Fields, Gary S. 1990. “Labor Market Modelling and the Urban Informal Sector: Theory and Evidence.” In David Turnham, Bernard Salomé, and Antoine Schwarz, eds., The Informal Sector Revisited. Paris: Organization for Economic Co-operation and Develoment.

Geroski, Paul A. 1991. Market Dynamics and Entry. Oxford: Blackwell Publishing.

Goedhuys, Micheline, and Leo Sleuwaegen. 2000. "Entrepreneurship and Growth of Entrepreneurial Firms in Cote d'Ivoire." Journal of Development Studies 36(3):123-46.

González de la Rocha, Mercedes. 1994. The Resources of Poverty: Women and Survival in a Mexican City. Oxford: Blackwell Publishing.

Hamilton, Barton H. 2000. "Does Entrepreneurship Pay? An Empirical Analysis of the Returns to SelfEmployment." Journal of Political Economy 108(3):604-31.

Harris, John R., and Michael P. Todaro. 1970. "Migration, Unemployment, and Development: A TwoSector Analysis.” American Economic Review 60(1):126-42.

Hart, Kieth. 1972. Employment, Income and Inequality: A Strategy for Increasing Productive Employment in Kenya. Geneva: International Labour Office.

Hart, Keith. 1973. "Informal Income Opportunities and Urban Employment in Ghana." Journal of Modern African Studies 11(3):61-89.

Hopenhayn, Hugo A. 1992. "Entry, Exit and Firm Dynamics in Long Run Equilibrium.” Econometrica 60(5):1127-50.

Johnson, William R. 1978. “A Theory of Job Shopping.” Quarterly Journal of Economics 92(2):261-78.

Jovanovic, Boyan. 1979. "Job Matching and the Theory of Turnover." Journal of Political Economy 87(5):972-90.

-1982. "Selection and the Evolution of Industry." Econometrica 50(3):649-70.

Liedholm, Carl. 2002. "Small Firm Dynamics: Evidence from Africa and Latin America." Small Business Economics 8(1-3):227-42.

Liedholm, Carl, and Donald C. Mead. 1999. Small Enterprises and Economic Development: The Dynamics of Micro and Small Enterprises. London: Routledge Press.

Loayza, Norman V., Ana Maria Oviedo, and Luis Serven. 2005. "The Impact of Regulation on Growth and Informality, Cross-Country Evidence.” Policy Research Working Paper 3623. World Bank, Washington, D.C.

Lucas, Robert E. Jr. 1978. "On the Size Distribution of Business Firms.” Bell Journal of Economics 9(2):508-23.

Maloney, William F. 1999. "Does Informality Imply Segmentation in Urban Labor Markets? Evidence From Sectoral Transitions in Mexico.” World Bank Economic Review 13(2):275-302.

- 2001. "Self-Employment and Labor Turnover in Developing Countries: Cross-Country Evidence." In S. Devarajan, F. Halsey Rogers, and L. Squire, eds., World Bank Economists Forum. Washington, D.C.: World Bank.

—. 2004. "Informality Revisited." World Development 32(7):1159-78.

McPherson, Michael A. 1995. "The Hazards of Small Firms in Southern Africa.” Journal of Development Studies 32(1):31-54.

- 1996. "Growth of Micro and Small Enterprises in Southern Africa." Journal of Development Economics 48(2):253-77.

Mead, D. M., and C. Liedholm. 1998. "The Dynamics of Micro and Small Enterprises in Developing Countries.” World Development 26(1):61-74.

Rees, Hedley, and Anup Shah. 1986. “An Empirical Analysis of Self-Employment in the U.K.” Journal of Applied Econometrics 1(1):95-108. 
Roberts, Mark J., and James R. Tybout, eds. 1997. Industrial Evolution in Developing Countries: Micro Patterns of Turnover, Productivity, and Market Structure. New York: Oxford University Press.

Tokman, Victor E. 1978. "An Exploration into the Nature of the Informal-Formal Sector Relationships." World Development 6(9/10):1065-75.

U.S. Small Business Administration. 2001. Small Business Economic Indicators: 2000. Washington, D.C.: Office of Advocacy.

Wagner, Joachim. 1994. "The Post-Entry Performance of New Small Firms in Germany Manufacturing Industries." Journal of Industrial Economics 42(2):141-54. 